\title{
Hyperlipaemia intensifies the course of acute oedematous and acute necrotising pancreatitis in
} the rat

\author{
B Hofbauer, H Friess, A Weber, K Baczako, P Kisling, M Schilling, W Uhl, C Dervenis, \\ M W Büchler
}

\begin{abstract}
Background-Serum triglyceride concentrations higher than 10 to $20 \mathrm{mmol} / \mathrm{l}$ are probably a risk factor for developing acute pancreatitis in humans.
\end{abstract}

Aims-To therefore analyse the influence of hyperlipaemia on the course of acute oedematous and acute necrotising pancreatitis in rats.

Subjects-Male Wistar rats were used in all experiments.

Methods-Six different groups of animals were used: two groups without pancreatitis (controls), two with acute oedematous pancreatitis, and two with acute necrotising pancreatitis. One group from each pair was treated with Triton WR 1339, which induces endogenous hyperlipaemia. Blood samples were taken from all subjects to measure triglyceride, cholesterol, amylase, and lipase. Pancreatic tissue samples were taken and the degree of pancreatic damage was judged microscopically.

Results-In the control groups no significant changes occurred, either in serum enzyme activities or in histology. The hyperlipaemic subgroup of animals with acute oedematous pancreatitis developed significantly higher $(p<0.001)$ serum amylase activities and a greater degree of histological damage $(p<0.01)$ than the animals of the non-hyperlipaemic acute oedematous pancreatitis group. In the animals with necrotising pancreatitis, serum lipase activity and the histological degree of pancreatic damage were significantly higher in the hyperlipaemic animals than in the non-hyperlipaemic animals.

Conclusion-This study shows that hyperlipaemia intensifies the course of acute oedematous and acute necrotising pancreatitis in rats.

(Gut 1996; 38: 753-758)

Keywords: hyperlipaemia, acute oedematous pancreatitis, acute necrotising pancreatitis.

Acute pancreatitis is a disease with an incidence varying from 47 to 110 cases per million per year in Western countries. ${ }^{1-3}$ Usually it is characterised clinically by acute abdominal pain and increased pancreatic enzymes in blood or urine, or both. Clinically, two different courses can be distinguished: acute oedematous pancreatitis and acute necrotising pancreatitis. In general, patients with acute oedematous pancreatitis respond well to conservative treatment, ${ }^{45}$ having a low morbidity and mortality. In contrast, $10-20 \%$ of the patients with acute pancreatitis develop intrapancreatic or extrapancreatic necrosis ${ }^{6}$ and life threatening systemic, metabolic, and organic complications. ${ }^{7-9}$ The most common aetiological factors in acute pancreatitis are alcohol abuse $(40 \%)$ and biliary tract stones $(40 \%)$. Other aetiologies, such as trauma, drugs or tumours, are rare and occur in about $20 \%$ of the cases. ${ }^{10}$

Hyperlipaemia is another aetiological factor and is often associated with relapsing periods of acute pancreatitis. A prevalence of hyperlipaemia in acute pancreatitis of between $4.5 \%$ and $47 \%$ has been reported in previous studies. ${ }^{11-16}$ This wide range of hyperlipaemia in acute pancreatitis seems to result from the patient populations, because patients with alcoholic pancreatitis have hyperlipaemia more frequently than patients with biliary pancreatitis. ${ }^{11} 14-15$ Serum triglyceride values higher than 10 to $20 \mathrm{mmol} / \mathrm{l} \mathrm{seem}$ to be a serious risk factor for developing acute pancreatitis. ${ }^{14} 15$ Particularly in patients suffering from familial hyperlipoproteinaemia (types I, IV, and $\mathrm{V}$ according to the classification of Frederickson), acute pancreatitis occurs with an incidence of up to $21 \% .^{111219}$ In those cases, patients have increased serum concentrations of chylomicrons and triglycerides. In type $\mathrm{V}$ of familial hyperlipoproteinaemia there are also high concentrations of pre- $\beta$-lipoproteins of very low density (VLDL) containing high concentrations of triglycerides. ${ }^{17} 18$

Several studies in humans and animals have been performed to evaluate hyperlipaemia as a risk factor for developing acute pancreatitis. Those studies showed that a high fat diet can change the susceptibility to experimental pancreatitis. Haig et al ascertained that overfed mongrel dogs had an increased likelihood of developing at least pancreatic oedema or even acute pancreatitis. ${ }^{20}$ Those findings confirmed the results of other studies that showed that acute experimental pancreatitis is more severe in normally fed animals than in semistarved animals. An explanation for this finding was that there is an adaptation of pancreatic enzymes because of the diet the animals were fed before developing pancreatitis. ${ }^{21} 22$ But this hypothesis was considered controversial in another study. ${ }^{23}$

Other studies using the isolated pancreatic acini model have suggested that damage to the
Correspondence to

Dr H Friess, Department of Surgery, University of Berne, Inselspital, $\mathrm{CH}-301$ Berne, Switzerland.

Accepted for publication 29 November 1995 
TABLE I Histological classification of acute pancreatitis according to the Spormann classification ${ }^{39}$

\begin{tabular}{lc}
\hline Histology & Points \\
\hline Oedema & \\
Mild & 1 \\
Moderate & 2 \\
Severe & 3 \\
Inflammatory infiltration \\
Mild & 1 \\
Moderate & 2 \\
Severe & 3 \\
Fat necrosis & 3 \\
Mild & 5 \\
Moderate & 7 \\
Severe & 3 \\
Parenchymal necrosis & \\
Singular & 5 \\
Sub lobular <1/3 & 7 \\
Lobular $>1 / 3$ & 7 \\
Haemorrhage & 3 \\
Mild & 5 \\
Moderate & 5 \\
Severe & 7 \\
\hline
\end{tabular}

acinar cells is caused by the cytotoxic effect of free fatty acids. These fatty acids are broken down products of triglycerides and were generated within the pancreas by the hydrolytic activity from the pancreatic lipase acting on triglycerides. ${ }^{24} 25$ There are two other hypotheses that could explain the mechanism by which hyperlipaemia causes parenchymal necrosis during acute pancreatitis. Trypsinogen could be activated by acidosis due to the presence of free fatty acids, ${ }^{26}{ }^{27}$ or the free fatty acids may disturb the microcirculation of the pancreas by damaging the vessels endothelium. ${ }^{25}$

However, there is not much information about the influence of hyperlipaemia on the course of acute pancreatitis. Previously, Buch et al confirmed that hyperlipaemia does not induce pancreatitis in humans directly, but can predispose to it or amplify it if there are other risk factors for acute pancreatitis. ${ }^{14}$ In this study the effect of endogenous hyperlipaemia on acute experimental pancreatitis was studied in rats using a caerulein model for acute oedematous pancreatitis and retrograde taurocholate injection in the pancreatic duct to induce acute necrotising pancreatitis.

\section{Methods}

Male Wistar rats with a body weight between $270 \mathrm{~g}$ and $300 \mathrm{~g}$ were used in all experiments. They were kept in single cages exposed to a 12 hour light/dark cycle with free access to chow and water. The chow (Altromin 1314, obtained from Altromin $\mathrm{GmbH}$, Lage, Germany) contained $23 \%$ protein, $5 \%$ fat, $6.5 \%$ ashes, $4.5 \%$ fibre, $47.5 \%$ nitrogen free extracts, and $3.5 \%$ water, minerals, and vitamins. ${ }^{28} 29$

After an overnight fast the animals were anaesthetised with a halothane-oxygen narcosis and a plastic catheter was placed in the right and left external jugular veins to take blood samples or to inject Triton WR 1339, saline solution, or infuse caerulein, or a combination of those. ${ }^{28}$

Blood samples were taken from all animals eight hours before and $0,45,90,135$, and 180 minutes after inducing pancreatitis. The blood samples were centrifuged at $3000 \mathrm{rpm}$ and the serum was stored in a $-30^{\circ} \mathrm{C}$ freezer until further analysis. The samples were then thawed at $+4^{\circ} \mathrm{C}$ and taken to measure triglyceride, cholesterol, amylase, and lipase.

Hyperlipaemia was induced by an intravenous injection of $0.25 \mathrm{ml}$ of a $10 \%$ Triton WR 1339 solution (Thomae GmbH, Biberach, Germany) in the right external jugular vein. Triton WR 1339 (polymeric p-iso-octyl polyoxyethylene phenol) is a non-ionic surface active detergent that leads to an increase of the endogenous triglyceride and cholesterol blood concentrations. ${ }^{30} 31$ We determined the required amount of Triton WR 1339 earlier in a test series of eight rats treated with rising volumes of a $10 \%$ Triton solution. A volume of $0.25 \mathrm{ml}$ of $10 \%$ Triton WR 1339 solution was found to induce maximal hyperlipaemia (data not shown). The non-hyperlipaemic animals received an injection of $0.25 \mathrm{ml}$ of a physiological saline solution intravenously instead of $0.25 \mathrm{ml} 10 \%$ Triton WR 1339 solution.
Acute oedematous pancreatitis was induced by infusion of $5 \mu \mathrm{g} / \mathrm{kg}$ body weight caerulein with a flow of $0.6 \mathrm{ml} / \mathrm{h}$ intravenously within three hours, as described in earlier studies. ${ }^{32-35}$

Acute haemorrhagic necrotising pancreatitis was induced by retrograde injection of $0 \cdot 1$ $\mathrm{ml} / 0 \cdot 1 \mathrm{~kg}$ body weight of $3 \%$ Na-taurocholate solution into the pancreatic duct with a pressure of $30 \mathrm{~cm} \mathrm{H}_{2} \mathrm{O}$, as previously described by other authors. ${ }^{36-38}$

For histopathological analysis, small pancreatic tissue samples were taken 90 and 180 minutes after inducing pancreatitis and immediately fixed in Bouin solution for 24 hours. Afterwards the tissue samples were stored in alcohol $(50 \%)$ and embedded in paraffin wax. The resulting $5 \mu \mathrm{m}$ sections were stained with haematoxylin and eosin reagent. To quantify the histological changes, two blinded independent pathologists judged the tissue samples using a point score as described by Spormann et al ${ }^{39}$ (Table I).

To explore the influence of hyperlipaemia on acute experimental pancreatitis we used six different groups of animals with 10 animals in each group (Table II). The animals of the first group $\mathrm{C}_{(\mathrm{Sal})}$ received $0.25 \mathrm{ml}$ saline (Sal) solution, and the animals of the second group $\mathrm{C}_{(\text {Tri) }}$ received $0.25 \mathrm{ml}$ of $10 \%$ Triton WR 1339 (Tri) solution both intravenously. In those two groups $\left(\mathrm{C}_{(\mathrm{Sal})}\right.$ and $\left.\mathrm{C}_{(\mathrm{Tri})}\right)$ no pancreatitis was induced. They formed the control (C) group.

Acute oedematous pancreatitis (OP) was induced in the third group $\mathrm{OP}_{(\mathrm{Car})}$ and the fourth group $\mathrm{OP}_{(\mathrm{Caer}+\mathrm{Tr})}$ by infusing caerulein (Caer) as described above. The animals of group OP $($ Caer+Tri) received an injection of 0.25 $\mathrm{ml}$ of $10 \%$ Triton WR 1339 (Tri) intravenously eight hours before inducing pancreatitis with the caerulein infusion.

Acute necrotising pancreatitis (NP) was induced in the fifth group $\mathrm{NP}_{(\mathrm{Tau})}$ and the sixth group $\mathrm{NP}_{(\mathrm{Tau}+\mathrm{Tr})}$ by retrograde injection of 3\% Na-taurocholate solution (Tau) into the main pancreatic duct. The animals of group

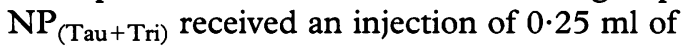
$10 \%$ Triton WR 1339 (Tri) intravenously eight hours before pancreatitis was induced.

\section{Results}

Overall, 68 male Wistar rats were used in this study. Eight of the 68 animals died prematurely from thrombo-embolism or circulatory breakdown, leaving 60 animals for experimentation, 10 in each of six groups.

In the clinical course, no changes occurred in the animals of both control groups C. The

TABLE II Experimental design. The animals were divided into six groups. Each group contained 10 rats

Control groups $(C)$
$\mathrm{I} ; \quad \mathrm{C}_{(\mathrm{Sal})}:$ saline solution

$\begin{array}{ll}\text { I; } & \mathrm{C}_{(\text {Sal) }} \text { : saline solution } \\ \text { II: } & \mathrm{C}_{(\text {Tri) }} \text { : Triton WR } 1339\end{array}$

Oedematous pancreatitis (OP)

III: $O P_{(\mathrm{Caer})}$ : saline and caerulein

IV: $\mathrm{OP}_{(\mathrm{Caer}+\mathrm{Tr})}$ : caerulein and Triton WR 1339

Necrotising pancreatitis (NP)

V: NP $($ Tau) : saline and Na-Taurocholate

VI: $N_{(\text {Tau }+ \text { Tri) }}$ : Na-taurocholate and Triton WR 1339 
TABLE III Serum triglyceride and cholesterol concentrations

\begin{tabular}{|c|c|c|c|c|}
\hline & -8 Hours & \pm 0 Hours & +90 Minutes & +180 Minutes \\
\hline $\begin{array}{l}\text { Triglyceride (median; mmo } \\
\text { Controls }\end{array}$ & & & & \\
\hline $\begin{array}{l}\text { Saline } \\
\text { Triton }\end{array}$ & $\begin{array}{l}0.56 \\
0.73\end{array}$ & $\left.\begin{array}{l}0 \cdot 42 \\
9 \cdot 05\end{array}\right] \star \star \star$ & $\left.\begin{array}{l}0 \cdot 09 \\
7 \cdot 51\end{array}\right]_{\star \star \star}$ & $\left.\begin{array}{l}0.08 \\
6 \cdot 63\end{array}\right]_{\star \star \star}$ \\
\hline $\begin{array}{l}\text { Oedematous pancreatitis } \\
\text { Caerulein + saline } \\
\text { Caerulein + Triton }\end{array}$ & $\begin{array}{l}0.50 \\
0.60\end{array}$ & $\left.\begin{array}{l}0 \cdot 39 \\
8 \cdot 59\end{array}\right] \star \star \star$ & $\left.\begin{array}{l}0 \cdot 23 \\
6 \cdot 68\end{array}\right] \star \star \star$ & $\left.\begin{array}{l}0 \cdot 16 \\
7 \cdot 05\end{array}\right]_{\star \star \star}$ \\
\hline $\begin{array}{l}\text { Necrotising pancreatitis } \\
\text { Taurocholate+ saline } \\
\text { Taurocholate + Triton }\end{array}$ & $\begin{array}{l}0.71 \\
0.59\end{array}$ & $\left.\begin{array}{l}0 \cdot 41 \\
6 \cdot 88\end{array}\right]_{\star \star \star}$ & $\left.\begin{array}{l}0 \cdot 24 \\
6 \cdot 77\end{array}\right] \star \star \star$ & $\left.\begin{array}{l}0 \cdot 25 \\
6 \cdot 07\end{array}\right]_{\star \star \star}$ \\
\hline $\begin{array}{l}\text { Cholesterol (median; mmol } \\
\text { Controls }\end{array}$ & & & & \\
\hline $\begin{array}{l}\text { Saline } \\
\text { Triton } \\
\text { Oedematous pancreatitis }\end{array}$ & $\begin{array}{l}1 \cdot 69 \\
1 \cdot 57\end{array}$ & $\left.\begin{array}{l}1 \cdot 79 \\
4 \cdot 24\end{array}\right] \star \star \star$ & $\left.\begin{array}{l}1 \cdot 54 \\
4 \cdot 21\end{array}\right] \star \star \star$ & $\left.\begin{array}{l}1 \cdot 29 \\
3 \cdot 95\end{array}\right]_{\star \star \star}$ \\
\hline $\begin{array}{l}\text { Caerulein +saline } \\
\text { Caerulein + Triton } \\
\text { Necrotising pancreatitis }\end{array}$ & $\begin{array}{l}1.49 \\
1.55\end{array}$ & $\left.\begin{array}{l}1 \cdot 52 \\
4 \cdot 24\end{array}\right] \star \star \star$ & $\left.\begin{array}{l}1 \cdot 57 \\
4 \cdot 04\end{array}\right]_{\star \star \star}$ & $\left.\begin{array}{l}1 \cdot 43 \\
3 \cdot 87\end{array}\right]_{\star \star \star}$ \\
\hline $\begin{array}{l}\text { Taurocholate + saline } \\
\text { Taurocholate + Triton }\end{array}$ & $\begin{array}{l}1.53 \\
1.59\end{array}$ & $\left.\begin{array}{l}1 \cdot 60 \\
3 \cdot 71\end{array}\right]_{\star \star \star}$ & $\left.\begin{array}{l}1 \cdot 49 \\
3 \cdot 72\end{array}\right] \star \star \star$ & $\left.\begin{array}{l}1 \cdot 26 \\
3 \cdot 21\end{array}\right]_{\star \star \star}$ \\
\hline
\end{tabular}

animals of group OP, with oedematous pancreatitis, developed the typical macro and microscopical changes of oedematous pancreatitis after infusion of caerulein. Retrograde infusion of $\mathrm{Na}$-taurocholate into the pancreatic duct led to haemorrhage and typical necrosis in all animals of the two necrotising pancreatitis $\left(\mathrm{NP}_{(\text {Tau })}, \mathrm{NP}_{(\text {Tau }+ \text { Tri) }}\right)$ groups. All animals treated with Triton WR 1339 developed hypertriglyceridaemia.

\section{CONTROL GROUPS (C), WITHOUT PANCREATITIS}

\section{Triglycerides}

The infusion of $0.25 \mathrm{ml}$ of $10 \%$ Triton WR 1339 (minus eight hours) resulted in an increase in serum triglyceride concentrations in group $\mathrm{C}_{(\mathrm{Tr})}$. The median serum triglyceride concentration before Triton WR 1339 infusion was $0.73 \mathrm{mmol} / 1$ (range: $0.1-1.69 \mathrm{mmol} / 1$ ), and after eight hours the median triglyceride value increased to $9.05 \mathrm{mmol} / \mathrm{l}$ (range: $2 \cdot 05-17 \cdot 42 \mathrm{mmol} / \mathrm{l})$. At 180 minutes after infusion of Triton WR 1339 the serum triglyceride concentrations decreased slightly (not significant) (Table III). The serum triglyceride values of group $\mathrm{C}_{(\mathrm{Sal})}$, the animals receiving only physiological saline solution, remained unchanged during the experiment (Table III).

\section{Cholesterol}

In the animals receiving $0.25 \mathrm{ml}$ Triton WR 1339 (group $\mathrm{C}_{(\mathrm{Tri})}$ ), the serum cholesterol concentrations showed the same courses as the serum triglyceride concentrations. The median cholesterol value before Triton WR 1339 injection was $1.57 \mathrm{mmol} / \mathrm{l}$ (range: $0.9-2.26$ $\mathrm{mmol} / \mathrm{l}$ ), increasing to $4 \cdot 24$ (range: $2 \cdot 10-5 \cdot 15$ ) after eight hours. At 180 minutes after infusion of Triton WR 1339 the serum cholesterol values decreased slightly (not significant) (Table III). The cholesterol concentrations of the animals receiving only saline solution (group $\mathrm{C}_{(\mathrm{Sal})}$ ) remained unchanged throughout the investigation (Table III).

\section{Amylase}

The serum amylase activities of the animals without pancreatitis decreased eight hours after the beginning of the investigation, both in the animals receiving only saline solution (group $\mathrm{C}_{(\mathrm{Sal})}$ ) and in the animals treated with Triton WR 1339 (group $\mathrm{C}_{(\text {Tri) }}$ ) (Table IV). The decrease was not significant (Table IV).

\section{Lipase}

The serum lipase activities in the control groups (C) increased slightly in the last 90 minutes of the experiment, both in the hyperlipaemic animals (group $\mathrm{C}_{(\mathrm{Tr} i)}$ ) and in the nonhyperlipaemic animals (group $\mathrm{C}_{(\mathrm{Sal})}$ ) (Table IV). However, the difference between the two groups was not significant (Table IV).

\section{Histology}

The animals of the control groups (C) showed no changes in the clinical course, whether receiving physiological saline solution (group $\mathrm{C}_{(\mathrm{Sal})}$ ) or Triton WR 1339 (group $\mathrm{C}_{(\text {Tri) }}$ ). There were no macroscopic changes of the pancreas in these two groups of animals during the whole examination time. The tissue samples taken at 90 and 180 minutes were judged histologically according to the point score of Spormann et al (Figure). Four hyperlipaemic animals of group $\mathrm{C}_{(\mathrm{Tr})}$ showed mild

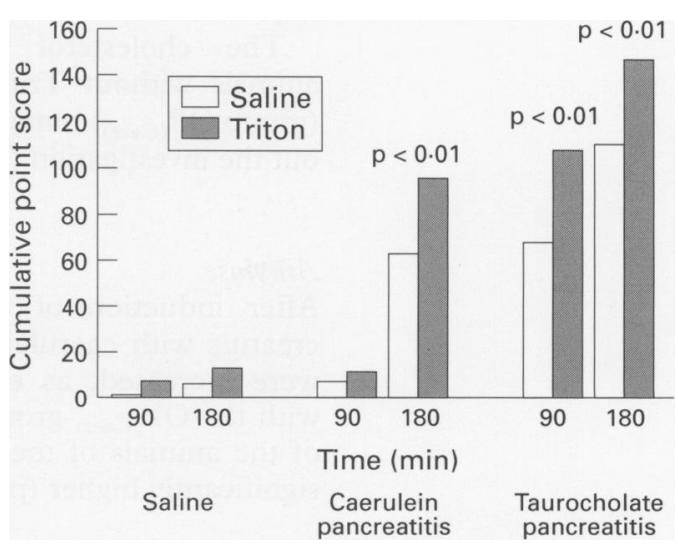

Histological degree of pancreatic damage in rats without pancreatitis, with caerulein induced pancreatitis, and with taurocholate induced pancreatitis. Animals with endogenous hyperlipaemia had a higher degree of pancreatic damage than animals without endogenous hyperlipaemia.

\begin{tabular}{|c|c|c|c|c|}
\hline & -8 Hours & \pm 0 Hours & +90 Minutes & +180 Minutes \\
\hline \multicolumn{5}{|l|}{$\begin{array}{l}\text { Amylase (median; } U / \text { ) } \\
\text { Controls }\end{array}$} \\
\hline Saline & 2493 & 2268 & 2275 & 2383 \\
\hline Triton & 2543 & 1941 & 1856 & 1885 \\
\hline \multicolumn{5}{|l|}{ Oedematous pancreatitis } \\
\hline Caerulein + saline & 2546 & 1963 & $3900]_{\star \star \star}$ & $8130]_{\star \star \star}$ \\
\hline Caerulein + Triton & 2719 & 2003 & $5680]^{\star \star \star}$ & $11010]^{\star \star \star}$ \\
\hline \multicolumn{5}{|l|}{ Necrotising pancreatitis } \\
\hline $\begin{array}{l}\text { Taurocholate + saline } \\
\text { Taurocholate + Triton }\end{array}$ & $\begin{array}{l}2705 \\
2531\end{array}$ & $\begin{array}{l}2268 \\
1979\end{array}$ & $\begin{array}{l}2816 \\
4200\end{array}$ & $\begin{array}{l}4220 \\
4070\end{array}$ \\
\hline \multicolumn{5}{|l|}{$\begin{array}{l}\text { Lipase (median; U/) } \\
\text { Controls }\end{array}$} \\
\hline Saline & 10 & 10 & 10 & 29 \\
\hline Triton & 10 & 10 & 10 & 45 \\
\hline \multicolumn{5}{|l|}{ Oedematous pancreatitis } \\
\hline Caerulein + saline & 10 & 10 & $1540]_{1+t}$ & $3480]_{1+t}$ \\
\hline $\begin{array}{l}\text { Caerulein + Triton } \\
\text { Necrotising }\end{array}$ & 10 & 10 & $2540]^{x \star}$ & $5430]^{\star \star \star}$ \\
\hline $\begin{array}{l}\text { Necrotising pancreatitis } \\
\text { Taurocholate + saline }\end{array}$ & 10 & 10 & $366]$ & 4751 \\
\hline Taurocholate + Triton & 10 & 10 & $1460]^{\star \star}$ & $1310]^{\star \star}$ \\
\hline
\end{tabular}


pancreatic oedema, whereas no histological changes occurred in the saline treated animals (group $\mathrm{C}_{(\mathrm{Sal})}$ ).

OEDEMATOUS PANCREATITIS, GROUP (OP)

Oedematous pancreatitis was induced as described previously by infusing $5 \mu \mathrm{g} / \mathrm{kg}$ body weight caerulein intravenously. Macroscopically, within one hour of caerulein infusion the animals developed a smooth oedema of the pancreas. This became more pronounced after three hours.

\section{Triglycerides}

The serum triglyceride concentrations of group $\mathrm{OP}_{(\mathrm{Caer})}$, the animals receiving only caerulein, remained unchanged during the experiments. In comparison, infusion of Triton WR 1339 resulted in a 14-fold increase in serum triglyceride values in group $\mathrm{OP}_{\text {(Caer+Tri) }}$. This difference between the $\mathrm{OP}_{\text {(Caer) }}$ group and the $\mathrm{OP}_{(\mathrm{Caer}+\mathrm{Tri})}$ group was significant $(p<0.001)$. The median serum triglyceride concentration of the $\mathrm{OP}_{(\mathrm{Caer}+\mathrm{Tri})}$ group was $0.6 \mathrm{mmol} / 1$ (range: $0.3-1.33$ $\mathrm{mmol} / \mathrm{l}$ ) (minus eight hours) before Triton WR 1339 infusion and increased to $8.59 \mathrm{mmol} / 1$ (range: 4.05-20.28 $\mathrm{mmol} / \mathrm{l}$ ) eight hours after Triton WR 1339 infusion. Eleven hours after the Triton WR 1339 infusion the serum triglyceride concentrations decreased only a little (Table III). Induction of acute pancreatitis by itself did not lead to a change in serum triglyceride values.

\section{Cholesterol}

The animals receiving $0.25 \mathrm{ml}$ Triton WR 1339 (group $\mathrm{OP}_{(\mathrm{Caer}+\mathrm{Tri})}$ ) had significantly $(p<0.001)$ higher serum cholesterol values than the non-hyperlipaemic animals (group $\left.\mathrm{OP}_{(\text {Caer })}\right)$. The median cholesterol value rose in group $\mathrm{OP}_{\text {(Caer+Tri) }}$ from $1.55 \mathrm{mmol} / \mathrm{l}$ (range: $1.33-1.89 \mathrm{mmol} / \mathrm{l}$ ) before to $4.24 \mathrm{mmol} / \mathrm{l}$ (range: $2 \cdot 10-5 \cdot 15 \mathrm{mmol} / \mathrm{l}$ ) eight hours after Triton WR 1339 infusion. Eleven hours after the Triton WR 1339 infusion the serum cholesterol values decreased only a little (Table III).

The cholesterol concentrations of the animals without Triton WR 1339 treatment (group $\left.\mathrm{OP}_{(\mathrm{Caer})}\right)$ remained unchanged throughout the investigation (Table III).

\section{Amylase}

After induction of acute oedematous pancreatitis with caerulein, the amylase activities were increased, as expected. In comparison with the $\mathrm{OP}_{(\mathrm{Caer})}$ group, the amylase activities of the animals of the $\mathrm{OP}_{(\mathrm{Caer}+\mathrm{Tri})}$ group were significantly higher $(p<0.001)$ (Table IV).

\section{Lipase}

The serum lipase values increased within 45 minutes of induction of pancreatitis with caerulein and showed a steep increase throughout the experiment. The animals of group $\mathrm{OP}_{(\mathrm{Caer}+\mathrm{Tr})}$ developed significantly higher $(p<0.001)$ serum lipase activities than the nonhyperlipaemic animals (Table IV).

\section{Histology}

Seven of the hyperlipaemic (group $\mathrm{OP}_{(\mathrm{Caer}+\mathrm{Tri})}$ ) and seven of the non-hyperlipaemic (group $\left.\mathrm{OP}_{(\mathrm{Caer})}\right)$ animals developed smooth oedema 90 minutes after pancreatitis induction. In addition, two hyperlipaemic animals had moderate oedema. No additional histological changes occurred after 90 minutes in the $\mathrm{OP}_{(\mathrm{Caer})}$ group. One hundred and eighty minutes after induction of acute oedematous pancreatitis, the cumulative point scores of the tissue samples were significantly higher $(p<0.01)$ in the hyperlipaemic animals (group $\left.\mathrm{OP}_{(\mathrm{Caer}+\mathrm{Tr})}\right)$ than in the animals receiving only caerulein infusion (group $\mathrm{OP}_{(\mathrm{Caer})}$ ) (Figure). The hyperlipaemic animals also showed singular parenchymal necrosis, whereas no parenchymal necrosis was seen in group $\mathrm{OP}_{(\mathrm{Caer})}$.

NECROTISING PANCREATITIS, GROUP (NP)

Beginning with the retrograde infusion of $\mathrm{Na}$ taurocholate into the pancreatic duct, extended areas of the pancreas turned red and developed a pronounced oedema. The gland lobules were pushed apart by severe swelling of the gland. In some areas haemorrhage occurred and the animals developed sanguineous ascites.

\section{Triglyceride and cholesterol}

The course of the serum cholesterol and triglyceride concentrations in the animals with necrotising pancreatitis were again the same as in the animals without pancreatitis. The triglyceride values of the animals not receiving Triton WR 1339 (group $\mathrm{NP}_{(\mathrm{Tau})}$ ) also did not change throughout the investigation (Table III). Infusion of Triton WR 1339 again led to endogenous hyperlipaemia in group $\mathrm{NP}_{(\text {Tau+Tri) }}$; eight hours after Triton WR 1339 application, the serum triglyceride and cholesterol values increased $11 \cdot 6$-fold and $2 \cdot 3$-fold, respectively (Table III). Induction of acute pancreatitis by itself did not lead to a change in serum triglyceride values.

\section{Amylase}

The serum amylase activities in the animals with necrotising pancreatitis were significantly increased after the induction of pancreatitis, but reached only half that of the animals with oedematous pancreatitis. Within 90 minutes of the induction of pancreatitis, the median amylase values rose from $1979 \mathrm{U} / 1( \pm 0)$ to $4200 \mathrm{U} / 1$ (+90 $\mathrm{min})$ in the $\mathrm{NP}_{\text {(Tau }+ \text { Tri) }}$ group. Three hours after pancreatitis induction the amylase values decreased a little (Table IV).

In the $\mathrm{NP}_{\text {(Tau) }}$ group the increase of the amylase values was slower than in the $\mathrm{NP}_{\text {(Tau+Tri) }}$ group (Table IV). 
Lipase

In the first eight hours of the experiment no changes in the lipase activities occurred in group $\mathrm{NP}_{(\mathrm{Tau})}$ or group $\mathrm{NP}_{(\text {Tau }}+$ Tri) . After induction of acute necrotising pancreatitis, the increase of the lipase values was greater in the $\mathbf{N P}_{\text {(Tau }+ \text { Tri) }}$ group than in the $\mathbf{N P}_{\text {(Tau }}$ group. The difference between the hyperlipaemic $\left(\mathrm{NP}_{\left(\mathrm{Tau}+\mathrm{Tr}_{\mathrm{i}}\right)}\right)$ group and the non-hyperlipaemic $\left(\mathbf{N P}_{(\mathrm{Tau})}\right)$ group was of less significance than the difference seen in group OP (Table IV).

\section{Histology}

Microscopically, all tissue samples taken from the animals suffering from necrotising pancreatitis showed oedema and a significantly $(p<0.01)$ higher cumulative point score in the hyperlipaemic animals $\left(\mathbf{N P}_{(\mathrm{Tau}+\mathrm{Tri})}\right)$ (point score 107) than in the non-hyperlipaemic animals $\left(\mathrm{NP}_{(\mathrm{Tau})}\right)$ (point score 67) 90 minutes after pancreatitis induction. Subsequently, 180 minutes after the induction of necrotising pancreatitis the point scores were 145 in the $\mathrm{NP}_{(\mathrm{Tau}+\mathrm{Tr})}$ group and 110 in the $\mathrm{NP}_{\text {(Tau) }}$ group. These differences were statistically significant $(p<0 \cdot 01)$.

\section{Discussion}

Compared with the main aetiological factors like gall stones and alcohol abuse, hyperlipaemia is of minor incidence in the development of acute pancreatitis. Nevertheless, several authors have reported that acute pancreatitis and hyperlipaemia coincide in $12 \%$ to $38 \%$ of patients. Also, patients suffering from hereditary hyperlipaemia have an incidence of up to $21 \%$ of acute pancreatitis. ${ }^{111219} \mathrm{How}$ ever, the mechanisms by which hyperlipaemia leads to acute pancreatitis are not known. One concept is that the damage of the acinar cells is caused by the cytotoxic effect of free fatty acids. These fatty acids are thought to be generated within the pancreas by the hydrolytic action from pancreatic lipase on triglycerides. ${ }^{25}$ In 1989, Nagai et al postulated that interstitial fission of triglycerides by the pancreatic lipase might lead to a detergent-like destruction of the cell membrane. ${ }^{40}$

The aim of this study was to analyse the effect of hyperlipaemia on the course of acute experimental pancreatitis in rats. Therefore, we divided the animals into six groups: two without pancreatitis, serving as the control; two with acute oedematous pancreatitis based on a caerulein model ${ }^{32-35}$; and two with acute haemorrhagic necrotising pancreatitis, based on the Na-taurocholate model. ${ }^{36-38}$ One group from each pair was pretreated with Triton WR 1339, which causes a significant increase of endogenous triglyceride and cholesterol blood concentrations. ${ }^{30} 31$ Animals in the other three groups received saline solution.

The rats without pancreatitis showed no clinical differences eight hours after Triton WR 1339 infusion compared with the animals with saline infusion. Macroscopically, the pancreases of the hyperlipaemic and the normal animals showed no differences. Microscopically, however, the animals treated with Triton WR 1339 showed smooth oedema, whereas no changes occurred in the non-hyperlipaemic animals. These morphological changes in the pancreases of rats with hyperlipaemia seem not to be caused by direct toxic effects of Triton WR 1339 administration. In our test series, rats were treated with rising volumes of Triton WR 1339 to determine the optimal dose of this drug needed to induce hyperlipaemia. Using twofold and fourfold higher doses of Triton WR 1339 in these experiments, we found mild oedema in four of 10 and three of 10 animals, respectively. The smooth pancreatic oedema in some of the rats treated with Triton WR 1339 could be the effect of the concentration of free fatty acids and decomposition products of fatty acids, which have cytotoxic effects. Saharia et al proposed that trypsinogen is activated in the acid milieu of the fatty acids and leads to autodigestion of the pancreas. ${ }^{25}$ Also, the detergent theory of Nagai et al, postulated in 1989 , could explain these minor histological differences. ${ }^{40}$ Hyperlipaemia seems to make the pancreas more susceptible to additional changes.

In the animals with acute oedematous pancreatitis (groups $\mathrm{OP}_{(\mathrm{Caer}+\mathrm{Tri})}$ and $\mathrm{OP}_{(\mathrm{Caer})}$ ) there were also no detectable differences macroscopically, either 90 or 180 minutes after inducing pancreatitis by a caerulein infusion. Histologically, smooth oedema and small vacuoles were detectable in both groups after 90 minutes of pancreatitis, being more noticeable in the hyperlipaemic group. The second samples, taken 180 minutes after the induction of pancreatitis, showed an increase in the Spormann point score of up to sixfold in the $\mathrm{OP}_{(\mathrm{Caer})}$ group and up to 10 -fold in the hyperlipaemic animals $\left(\mathrm{OP}_{(\mathrm{Caer}+\mathrm{Tri})}\right)$ in comparison with the control groups $\left(\mathrm{C}_{(\mathrm{Sal})}, \mathrm{C}_{(\mathrm{Tri})}\right)$. The animals receiving Triton $\left(\mathrm{OP}_{(\mathrm{Caer}+\mathrm{Tri})}\right)$ showed increased inflammation, fat necrosis, haemorrhage, and even pancreatic necrosis, which did not occur in the $\mathrm{OP}_{(\mathrm{Caer})}$ group. Secretory vacuoles are increased in size and number in animals with acute oedematous pancreatitis. These vacuoles are typically seen in the early stages of acute pancreatitis. They are the result of a fusion of lysosomal and zymogenal granules, with subsequent activation of proteases and cell destruction. ${ }^{4142}$ The loss of activated enzymes into the interstitial tissue might lead to higher concentrations of free fatty acids in the hyperlipaemic animals, probably resulting from the generation of fatty acids by pancreatic lipase from the increased triglyceride values. ${ }^{25} 40$ Subsequently, the cytotoxic effects of free fatty acids might lead to a significant increase in histological damage in the animals having the Triton injection (group $\left.\mathrm{OP}_{(\mathrm{Caer}+\mathrm{Tri})}\right)$ before the induction of pancreatitis.

In the animals having acute necrotising pancreatitis, the serum lipase activity was significantly higher in the hyperlipaemic animals compared with the animals with normal triglyceride and cholesterol serum values. By histological analysis, pancreatic damage occurred earlier and 
was more severe in the hyperlipaemic than in the non-hyperlipaemic animals. The degree of pancreatic damage was significantly higher $(\mathrm{p}<0.01)$ in the hyperlipaemic necrotising pancreatitis group after 90 and 180 minutes compared with the non-hyperlipaemic groups.

Similar results were reported by Haig et al, ${ }^{20}$ who induced acute pancreatitis in mongrel dogs. Dogs that had been maintained on a high fat diet for six weeks before pancreatitis became more acutely ill and sustained greater injury to the pancreas than those animals ingesting a balanced diet. The hypothesis that hyperlipaemia does not induce pancreatitis directly but rather causes a predisposition to or amplifies acute pancreatitis if there are other risk factors for acute pancreatitis has been supported in other studies. ${ }^{14} 1943$ Also, in this study only the animals that received a Triton WR 1339 injection developed hyperlipaemia, regardless of whether acute pancreatitis was present. Other authors have hypothesised that pancreatitis might induce hyperlipaemia by itself. ${ }^{44}$ Because our investigation was limited to three hours, it is probable that there was not enough time for hyperlipaemia to develop.

It is well known that relapsing episodes of acute pancreatitis are occasionally associated with hyperlipaemia. ${ }^{11-16}$ Particularly in patients suffering from familial hyperlipoproteinaemia (types I, IV, and V according to the classification of Frederickson), acute pancreatitis has an incidence of up to $21 \%$. $^{12} 19$ Those clinical findings have been confirmed in several studies of experimental pancreatitis. ${ }^{20-22} 2538$ Our experimental data show that hyperlipaemia intensifies the course of both acute oedematous and acute necrotising pancreatitis in rats. These findings suggest that hyperlipaemia might also be an important risk factor in the course of acute pancreatitis in humans. Additional studies are needed to explore the clinical significance of these findings.

1 Bourke JB, Giggs JA, Ebdon DS. Variations in the incidence and the spatial distribution of patients with primary acute pancreatitis in Nottingham 1969-1976. Gut 1979; 20: pancreatitis

2 Corfield AP, Cooper MJ, Williamson RCN. Acute pancreatitis: a lethal disease of increasing incidence. Gut creatitis: a lethal

3 Malfertheiner P, Dominguez-Munoz JE. Diagnosis and staging of acute pancreatitis. Dig Surg 1994; 11: 198-208. 4 Banks PA. Acute pancreatitis: Conservative management. Dig Surg 1994; 11: 220-5.

5 Büchler M. Objectification of the severity of acute pancreatitis. Hepatogastroenterology 1991; 38: 101-8.

6 Becker V. Pathological anatomy and pathogenesis of acute pancreatitis. World f Surg 1981; 5: 303-13.

7 Beger HG, Bittner R, Block S, Büchler M. Bacterial contamination of pancreatic necrosis: a prospective clinical mination of pancreatic necrosis: a prosp

8 Büchler M, Malfertheiner P, Schädlich H, Nevalainen TJ, Friess H, Beger HG. Role of phospholipase A2 in human acute pancreatitis. Gastroenterology 1989; 97: 1521-6.

$9 \mathrm{McF}$ adden DW. Organ failure and multiple organ failure in pancreatitis. Pancreas 1991; 6: 37-43.

10 Steer ML, Saluja AK. Etiology and pathogenesis of acute pancreatitis. In: Beger HG, Büchler M, Malfertheiner P, eds. Standards in pancreatic surgery. Berlin: Springer, 1993: 13-33.

11 Cameron JL, Capuzzi DM, Zuidema GD, Margolis S. Acute pancreatitis with hyperlipemia: the incidence of lipid abnormalities in acute pancreatitis. Ann Surg 1973; 177: 483-9.

12 Farmer RG, Winkelmann EI, Brown HB, Lewis LA. Hyperlipoproteinemia and pancreatitis. Am F Med 1973; 54: $161-5$.

13 Greenberger NJ, Hatch FT, Drummey GD, Isselbacher KJ. Pancreatitis and hyperlipemia. Medicine 1966; 45: 161-75.

14 Buch A, Buch J, Carlsen A, Schmidt A. Hyperlipemia and pancreatitis. World f Surg 1980; 4: 307-14.

15 Dickson AP, O'Neill J, Imrie CW. Hyperlipidaemia, alcohol abuse and acute pancreatitis. Br f Surg 1984; 71: 685-8.

16 Dominguez-Munoz JE, Malfertheiner $\mathrm{P}$, Ditschuneit $\mathrm{HH}$ Blanco-Chavez $\mathrm{J}$, Uhl $\mathrm{W}$, Büchler $\mathrm{M}$, et al. Hyperlipidemia in acute pancreatitis. Relationship with etiology, onset, and severity of the disease. Int $\mathcal{f}$ Pancreatol 1991; 10: 261-7.

17 Ditschuneit H. Hyperlipoproteinemia in the pathogenesis of acute pancreatitis. Acute Pancreatitis. Research and clinical management. Berlin: Springer, 1987: 32-40.

18 Toskes PP. Hyperlipidemic pancreatitis. Gastroenterol Clin North Am 1990; 19: 783-91.

19 Klatskin G, Gordon M. Relationship between relapsing pancreatitis and hyperlipemia. Am $\mathcal{F}$ Med 1952; 12: 3-23. 20 Haig THB. Experimental pancreatitis intensified by a high fat diet. Surg Gynecol Obstet 1970; 131: 914-8.

21 Goodhead B. Importance of nutrition in the pathogenesis of experimental pancreatitis in dogs. Arch Surg 1971; 103: 724-7.

22 Haig THB, Moffat JG, Thompson AG. Nutrition as a factor in experimental pancreatitis. Can f Surg 1965; 8: 312-6.

23 Haig THB. Pancreatic digestive enzymes: influence of a diet that augments pancreatitis. $\mathcal{F}$ Surg Res 1970; 10: 601-7.

24 Havel RJ. Pathogenesis, differentiation and management of hypertriglyceridemia. Adv Intern Med 1967; 15: 117-54. 25 Saharia P, Margolis S, Zuidema MD, Cameron JL. Acute pancreatitis with hyperlipemia: studies with an isolated perfused canine pancreas. Surgery 1977; 82: 60-7.

26 Greenbaum LM, Hirshkowik A, Shoichet I. The activation of trypsinogen by cathepsin B. $\mathcal{F}$ Biol Chem 1959; 234: 2885-90.

27 Niederau C, Grendell JH. Intracellular vacuoles in experimental acute pancreatitis are an acidified compartment. $\mathcal{F}$ Clin Invest 1986; 81: 229-36.

28 Friess H, Weber A, Büchler M. Standards in monitoring acute experimental pancreatitis. Eur Surg Res 1992; 24: $1-13$.

29 Büchler M, Friess H, Uhl W, Beger HG. Clinical relevance of experimental acute pancreatitis. Eur Surg Res 1992; 24: 85-8.

30 Otway S, Robinson DS. The effect of a non-ionic detergent (Triton WR 1339) on removal of triglyceride fatty acids from the blood of the rat. $\mathcal{F}$ Physiol 1967; 170: 309-19.

31 Otway S, Robinson DS. The use of a non-ionic detergent (Triton WR 1339) to determine rates of triglyceride entry into the circulation of the rat under different physiological conditions. F Physiol 1967; 190: 321-32.

32 Adler G, Hupp T, Kern HF. Course and spontaneous regression of acute pancreatitis in the rat. Virchows Arch A Pathol Anat and Histol 1979; 382: 31-47.

33 Kern HF. Effect of administration of gastrointestinal hormones on the pancreas. Hepatogastroenterology 1980; 27: 407-10.

34 Lampel M, Kern HF. Acute interstitial pancreatitis in the rat induced by extensive doses of a pancreatic secretagogue. Virchows Arch A Pathol Anat and Histol 1977; 373: 97-117.

35 Saluja A, Saito I, Saluja M, Houlihan MJ, Powers RE, Meldolesi $\mathrm{J}$, et al. In vivo rat pancreatic cell function during supramaximal stimulation with cerulein. $A m f$ Physiol 1985; 249: 702-10.

36 Aho HJ, Koskensalo SM, Nevalainen TJ. Experimental pancreatitis in the rat: Sodium taurocholate-induced acute hemorrhagic pancreatitis. Scand $\mathcal{f}$ Gastroenterol 1980; 15: 411-6.

37 Lankisch PG, Winckler K, Bokermann M, Schmidt H, Creutzfeld $W$. The influence of glucagon on acute experimental pancreatitis in the rat. Scand $\mathcal{F}$ Gastroenterol 1974; 9: 725-9

38 Wanke M. Experimental acute pancreatitis. Curr Top Pathol 1970; 52: 64-142.

39 Spormann H, Sokolowsky A, Letko G. Effect of temporary ischemia upon development and histological patterns of acute pancreatitis in the rat. Pathol Res Pract 1989; 184: 507-13.

40 Nagai H, Heinrich H, Wünsch P-H, Fischbach W, Mössner J. Role of pancreatic enzymes and their substrates in J. Role of pancreatic enzymes and their substrates in 838-47.

41 Steer ML. How and where does acute pancreatitis begin? Arch Surg 1992; 127: 1350-3.

42 Steer ML, Meldolesi J. The cell biology of acute experimental pancreatitis. N Engl f Med 1987; 316: 156-9.

43 Stackhouse KL, Glass DD, Zimmermann B. Relationships of lipoprotein lipase and hyperlipemia in pancreatitis. Surg Forum 1966; 17: 343-4.

44 Wang C, Strauss L, Adlersburg D. Experimental pancreatitis and plasma lipids. Gastroenterology 1958; 35: 465. 